\title{
Habitat use of juvenile goliath grouper Epinephelus itajara in the Florida Keys, USA
}

\author{
Sarah Frias-Torres* \\ Cooperative Institute for Marine and Atmospheric Studies (RSMAS-UM), NOAA-NMFS Southeast Fisheries Science Center, \\ 75 Virginia Beach Drive, Miami, Florida 33149-1003, USA
}

\begin{abstract}
This study reports the distribution, abundance and habitat use of juvenile goliath grouper Epinephelus itajara along fringing red mangrove Rhizophora mangle shorelines of the Florida Keys, USA. The species has been protected from fishing in US waters since 1992, after reaching commercial extinction, yet juvenile habitat use remains poorly studied. The aim of this study was to evaluate the importance of underwater mangrove habitat structure and complexity in determining distribution of juvenile goliath grouper in the Florida Keys. Visual underwater surveys were used to record juvenile presence, abundance and size. Habitat characteristics as continuous variables (depth, canopy, overhang and prop root width) and nominal variables (bottom type, sun exposure, shoreline shape and shoreline type) were also recorded. Juveniles aggregated in sites with high structural complexity, soft sediment and eroded shorelines. Well-developed fringing red mangrove shorelines were the preferred juvenile goliath grouper habitat.
\end{abstract}

KEY WORDS: Mangroves · Nursery $\cdot$ Epinephelus itajara $\cdot$ Essential fish habitat $\cdot$ Visual census

\section{INTRODUCTION}

The goliath grouper Epinephelus itajara is the largest grouper in the Atlantic Ocean and one of the 2 largest species of groupers in the world, exceeding $2 \mathrm{~m}$ in total length, and $400 \mathrm{~kg}$ in weight (Sadovy \& Eklund 1999). It is one of few groupers able to live in brackish water, and tolerate low oxygen levels, at least as juveniles (Smith 1976). The species occurs in tropical and subtropical waters of the Atlantic Ocean, from Florida to Brazil (to Sao Paulo), throughout the Gulf of Mexico, the Caribbean and along the western African coast from Senegal to Congo. It is also present in the eastern Pacific from the Gulf of California to Peru (Heemstra \& Randall 1993).

Epinephelus itajara are extremely vulnerable to overfishing (Bullock et al. 1992) due to a combination of life history traits typical in large serranid fish, such as slow growth, long life (3 or 4 decades), late sexual maturity (5 yr), strong site fidelity, and formation of spawning aggregations (Bullock et al. 1992, Huntsman et al. 1999, Sadovy \& Eklund 1999, Eklund \& Schull 2001). In 1994, commercial extinction prompted inclu- sion on the World Conservation Union's Red List of Threatened Species as critically endangered (Hudson \& Mace 1996). A fishing ban has been in effect in US waters since 1992 (Sadovy \& Eklund 1999).

The species is mangrove-dependent, and shows a distinct size-related habitat shift, with juveniles ( $<110 \mathrm{~cm}$ total length, TL) found exclusively in fringing red mangrove Rhizophora mangle shorelines and adults ( $>110 \mathrm{~cm}$ TL) found in coral reefs, isolated patch reefs, reef/rock ledges, and artificial structures (Bohnsack \& al. 1999, Sadovy \& Eklund 1999). Juveniles are rare in most fringing red mangrove habitats of southern Florida. When the fishing ban started, most juveniles were only found in the mangrove shorelines of the Ten Thousand Islands, southwest Florida, considered the historical center of abundance for this species (Sadovy \& Eklund 1999). Previous studies of juvenile home ranges and water quality (A. M. Eklund et al. unpubl. data), and movement patterns (Eklund \& Schull 2001) were conducted exclusively in southwest Florida, where lack of visibility had prevented visual underwater census and studies of habitat preferences were done using traps. No previous studies have 
examined mangrove habitat use for this species in the Florida Keys.

A decade after protection started, fishermen reported sightings in the Florida Keys mangroves, which provided an indication that the species might be returning to its original distribution range. The aim of this study is to investigate the importance of underwater mangrove habitat structure and complexity in determining distribution of juvenile Epinephelus itajara along fringing red mangrove shorelines in the Florida Keys. The objectives were to quantify habitat preferences, and evaluate if differences in habitat features along the shoreline explain juvenile distribution.

\section{MATERIALS AND METHODS}

Study area. This study was conducted in 3 channels of the Lower Florida Keys: Niles, Kemp and Pine Channels, between latitudes $24^{\circ} 45^{\prime} \mathrm{N}$ and $24^{\circ} 37.5^{\prime} \mathrm{N}$, and longitudes $81^{\circ} 27.5^{\prime} \mathrm{W}$ and $81^{\circ} 22.5^{\prime} \mathrm{W}$, within the Florida Keys National Marine Sanctuary (Fig. 1). Mangroves in this region associate with sediment deposits over the shallow Pleistocene formations of the lower Florida Peninsula (Gilmore \& Snedaker 1993). These are low-energy shorelines where fine sediments, muds and clays settle (Odum et al. 1982). The area contains 3 of the 5 characteristic mangrove forest types of southern Florida (Gilmore \& Snedaker 1993): fringe forests, dwarf mangrove forests and overwash mangrove islands. The dominant species is red mangrove Rhizophora mangle. Mangrove fringe forests occur along large keys separated by wide tidal channels that connect the Gulf of Mexico with the Atlantic Ocean in a northwest to southeast axis. Here, the canopy foliage forms a vertical wall reaching up to $7 \mathrm{~m}$. Dwarf mangrove forests occur along portions of the larger keys, where rock substrate, freshwater flow and tidal activity are limited. Dwarf mangroves have a maximum height at maturity of about $1 \mathrm{~m}$, and develop an extensive prop root system. Small, remote overwash mangrove islands abound on the Gulf side of the channels. Tidal waters overwash these islands in almost every tidal cycle, and tidal currents often erode the peat deposits forming underwater ledges or undercuts.
Fieldwork. Fieldwork was planned with the aid of aerial photographs (Digital Orthophotos acquired from the U.S. Geological Service) that were integrated into a Geographic Information System (GIS, ESRI ArcView 3.2a) followed by on-site underwater inspections of Pine, Niles and Kemp Channels. Based on preliminary work, the experimental design included a directed, non-random sampling in Kemp, Niles and Pine Channels, and a stratified random sampling (Underwood 1997) in Niles Channel. Non-random sites were selected based on reports from fishermen, and preliminary surveys which confirmed juvenile occurrence. The study area selected is representative of the fringing red mangrove shorelines of the Florida Keys (Fig. 1). This phase of the research was also used as diver calibration for the visual surveys.

Criteria for strata classification for random sampling included island size as big ( $>1 \mathrm{~km}$ long) versus small ( $<1 \mathrm{~km}$ long) keys, and location within Niles channel. The shorelines of Niles Channel were separated into 5 different strata: CS (channel small keys), NWS (northwest small keys), NES (northeast small keys), EB (eastern big keys), and WB (western big keys) (Fig. 1). Maximum tide amplitude in all strata is $0.5 \mathrm{~m}$. In order to sample each stratum in proportion to its shoreline length, strata were measured in GIS, a list of random numbers for each size was generated, and sample locations were assigned in GIS as latitude-

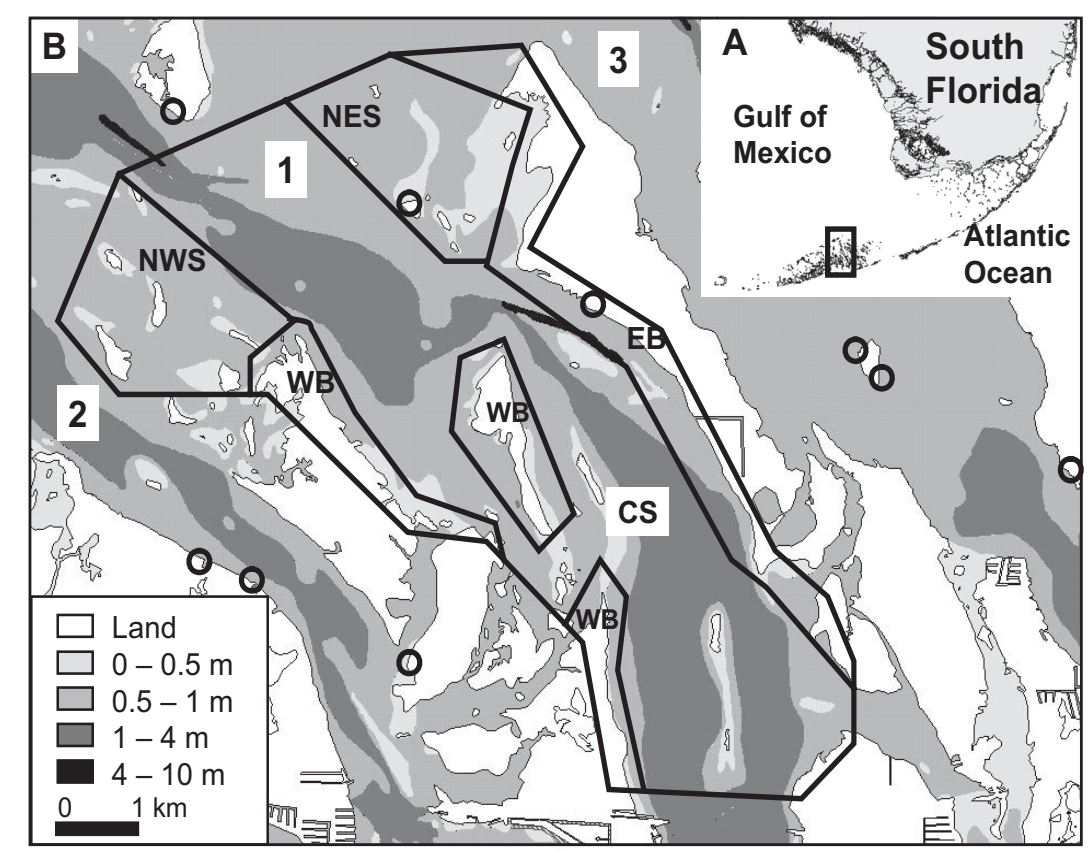

Fig. 1. Study area. (A) South Florida and Florida Keys. (B) Location of Niles (1), Kemp (2) and Pine (3) Channels and the 5 strata used for the random sampling (see key). Circles indicate the location of non-random transects. EB: eastern big keys; WB: western big keys; NES: northeastern small keys; NWS: northwestern small keys; CS: channel small keys 
longitude coordinates. A Garmin ${ }^{\circledR}$ Venture Global Positioning System (GPS) and a printout of the aerial photographs were used to reach the transect locations in the field.

A total of 100 stratified random transects (14 on CS, 16 in NWS, 10 in NES, 26 in EB and 34 in WB) and 9 non-random transects (goliath grouper, GG) were surveyed, from May 17 to July 30 2004. Depths sampled ranged from 0 to $4 \mathrm{~m}$. Visual surveys consisted of a $30 \mathrm{~m}$ long, $2 \mathrm{~m}$ wide, belt-shaped transect method along the shoreline, considered a rapid and effective technique for gathering data in mangrove-lined shorelines (Serafy et al. 2003). The method involved snorkelling parallel to the shore and recording the number and size of juveniles. The area censused per transect was $60 \mathrm{~m}^{2}$. Crevices or undercuts found along transects were examined by free-diving. The TL of the fish was measured comparing them to a $1 \mathrm{~m}$ long PVC pole, labelled at $5 \mathrm{~cm}$ intervals, with a $30 \mathrm{~cm}$ ruler attached perpendicular to the end. For fish with TL $<30 \mathrm{~cm}$, the ruler was used measuring to the nearest $\mathrm{cm}$. For fish with TL $>30 \mathrm{~cm}$, the pole was used measuring in $5 \mathrm{~cm}$ intervals. Underwater visual surveys were conducted between 09:00 and 17:00 h, with at least $250 \mathrm{~cm}$ visibility and during flood and high tides in order to navigate through the shallows and sand bars in the channels. The same diver did all visual censuses. To minimize the effect of silt disturbance on water quality, visual transects were performed by snorkelling and free-diving against the current.

The structural habitat was measured on both ends of each transect with continuous and nominal variables. Therefore, the 109 transects surveyed resulted in 218 habitat points. Continuous variables were measured to the nearest centimeter with a waterproof tape. These included bottom depth, and the width of prop roots, overhangs and canopy. Nominal variables were: bottom type (mud, hard, sand, or seagrass), shoreline shape (straight, concave or convex), shoreline type (depositional or erosional) and sun exposure (full sun, medium, or shade).

Data analysis. The null hypothesis was that juveniles were distributed randomly along the fringing red mangrove habitat. Non-random transects where included as an additional strata (GG, goliath grouper strata) in all analysis. Statistical analyses were performed using Statistica 6.0 computer software. Original and transformed (log) data were tested for the assumptions of normality and equal variance. The dispersion index (variance/mean) was calculated to determine juvenile distribution (Sokal \& Rohlf 1995).

Raw and log-transformed data did not meet the assumptions of equal variance needed for analysis of variance (ANOVA). To test for differences based on juvenile presence, variations in depth and prop root, overhang, and canopy width were analyzed using a Mann-Whitney Rank Sum Test while variations in bottom type, shoreline type and shape, and light level were analyzed using chi-square tests of association.

To test for differences based on transect habitat characteristics, coding was used to include nominal variables in the analyses. Principal component analysis (PCA) was used to examine affinities among transects, reduce the number of variables and detect relationships between variables. Resulting principal components were presented in a graph. Cluster analysis was used to examine affinities among strata. Ward's minimum-variance method (Milligan 1980) was used. The analysis was conducted on a matrix composed of strata mean values of the log-transformed data for each variable (Serafy et al. 1997). Resulting intercluster distances were presented in a dendrogram.

\section{RESULTS}

A total of 52 juvenile Epinepheus itajara were found, 13 in the random transects and 39 in the nonrandom transects. The average TL was $42 \mathrm{~cm}$ (SE 2.5), range 12 to $110 \mathrm{~cm}$ TL. The dispersion index was greater than 1; hence, fish occurrence followed a contagious distribution or negative binomial (Sokal \& Rohlf 1995). Juvenile density was 0.002 fish $\mathrm{m}^{-2}$ in the random transects $\left(6000 \mathrm{~m}^{2}\right.$ sampled) and 0.07 fish $\mathrm{m}^{-2}$ in the non-random transects $\left(540 \mathrm{~m}^{2}\right.$ sampled). Juveniles were found in 4 types of natural habitat (Fig. 2): overhangs, undercuts, dead trees and limestone solution holes. Overhangs and undercuts were an integral part of the fringing red mangrove shoreline. Dead trees and limestone solution holes were rarely found along the shoreline or adjacent to the mangrove habitat. Six juveniles were found in artificial habitats consisting of small-boat wrecks in 2 man-made canals cut through the mangrove canopy. However, artificial habitat data were not included in the analysis.

Juvenile occurrence was significantly influenced by all continuous habitat variables (Mann-Whitney Rank Sum Tests, p $<0.05$, Fig. 3). Juveniles preferred deeper $(>80 \mathrm{~cm})$ sites and wider habitat (canopy, overhangs) and avoided sites with extensive $(\sim 300 \mathrm{~cm}$ width) prop roots. Juveniles preferred soft sediment (mud, sand), concave and erosional shorelines. Chisquare tests of association were significant $(p<0.05)$ for bottom type, shoreline shape and shoreline type, but were not significant $(p>0.05)$ for sun exposure. The association between juvenile presence and each variable was negative for hard substrata, positive for concave shoreline shape and positive for erosional shoreline type. 

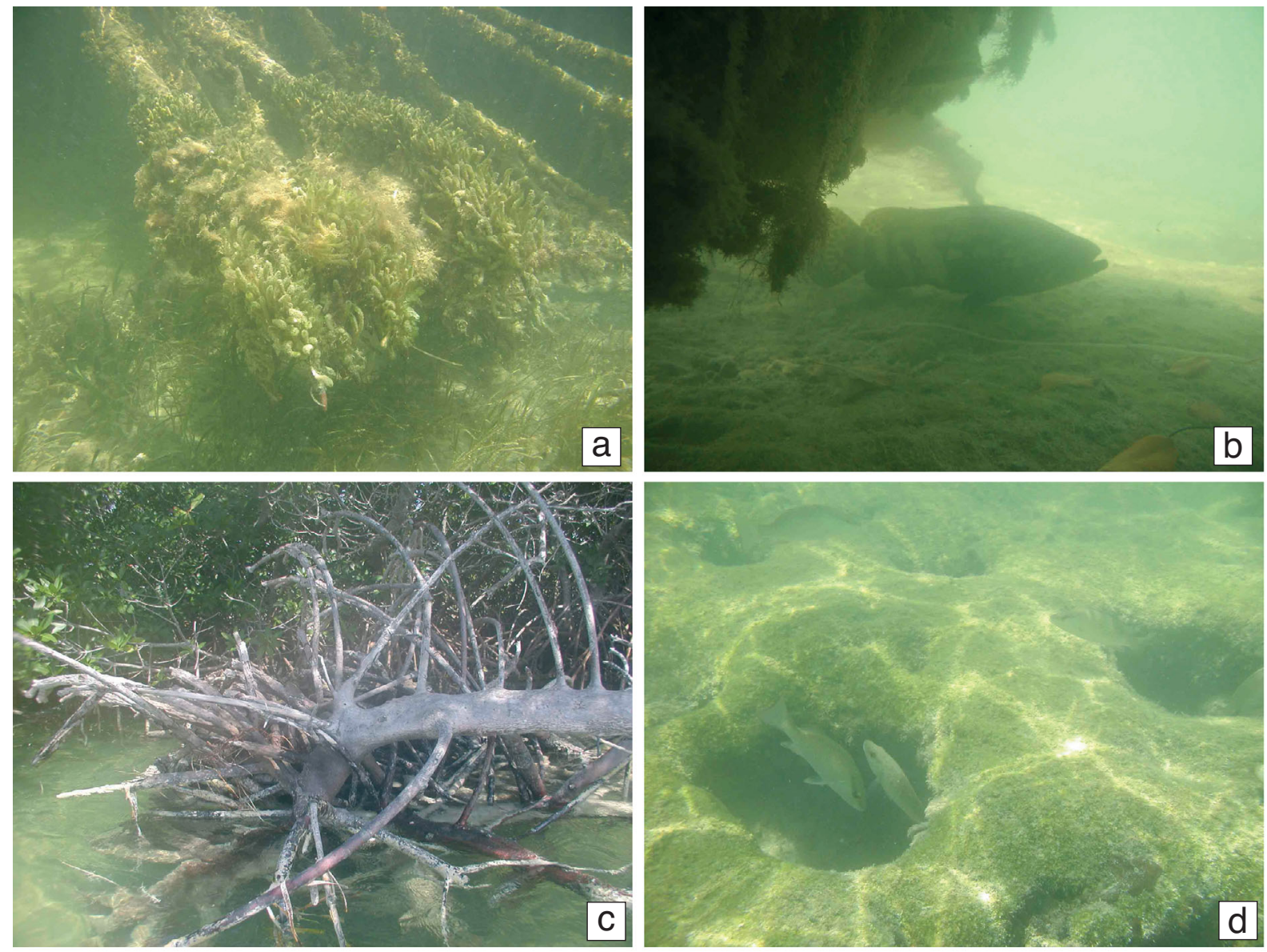

Fig. 2. Epinephelus itajara. Mangrove microhabitats used by juveniles in the study area, Florida Keys. (a) Overhangs, (b) undercuts (E. itajara shown), (c) dead trees, (d) limestone solution holes (grey snapper Lutjanus griseus shown)

Juveniles were found only in the non-random strata $\mathrm{GG}$, and 3 of the random strata (NES, EB, and WB). Undercuts were found only in GG and NES strata. In PCA, the first 3 factors, which explained $68.3 \%$ of the variability, had eigenvalues greater than 1 , and following the Kaiser criterion they should be retained (Kaiser 1960). However, the factor loadings (varimax normalized) provide an interpretable solution only when the first 2 factors are used (which explain $55.2 \%$ of the variability). In the first principal component, the highest factor loadings $(>0.7)$ were found in overhang and canopy width and light level. This component is indicative of 'underwater structural complexity'. In the second principal component, the highest factor loadings ( $>0.7)$ were found in depth and shoreline shape. This component is indicative of 'erosional and deeper habitat' (Fig. 4). Cluster analysis was performed on continuous and nominal variables. The analysis produced 2 major clusters. One cluster contained the GG and NES strata. The second cluster contained the remaining strata, with $\mathrm{EB}$ and WB grouped together (Fig. 5).

\section{DISCUSSION}

Patterns of distribution and habitat preferences reported here reject the hypothesis that juveniles are distributed randomly along the fringing red mangrove

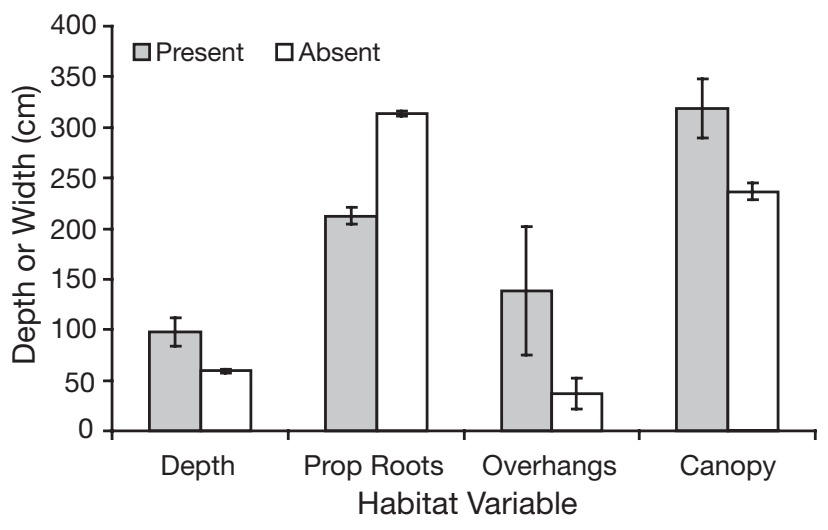

Fig. 3. Epinephelus itajara. Juvenile presence ( $\mathrm{n}=15$ transects) and absence ( $\mathrm{n}=94$ transects) related to continuous habitat variables. All Mann-Whitney Rank Sum tests were significant $(p<0.05)$. Values are means $\pm 1 \mathrm{SE}$ 


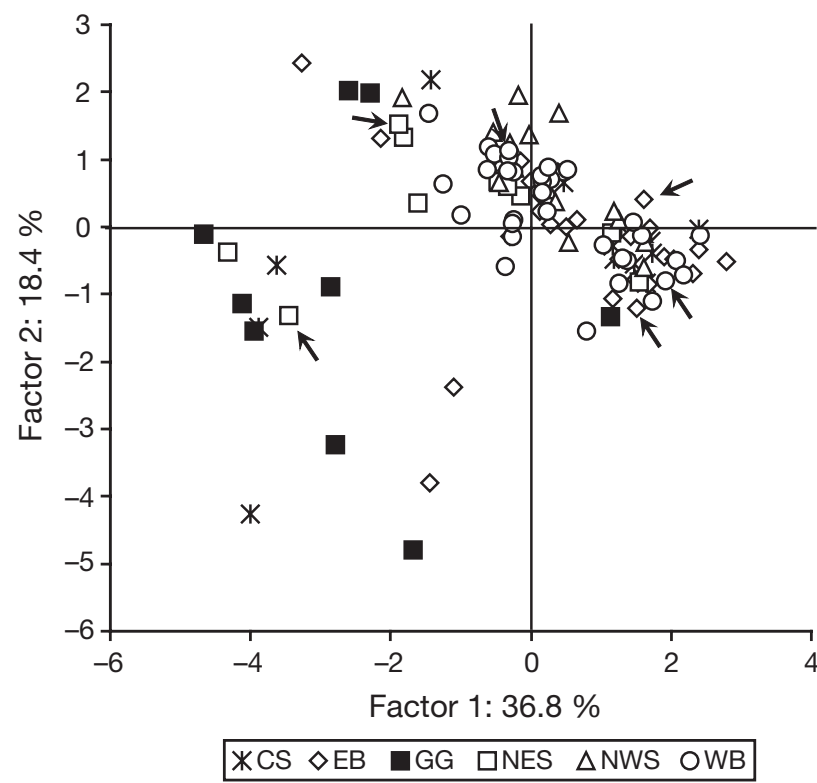

Fig. 4. Principal component analysis derived from the continuous and nominal variables for the 109 transects surveyed. Arrows indicate non-GG transects with juvenile goliath grouper presence. CS: channel small keys; EB: eastern big keys; GG: goliath grouper non-random transects; NES: northeast small keys; NWS: northwest small keys; WB : western big keys

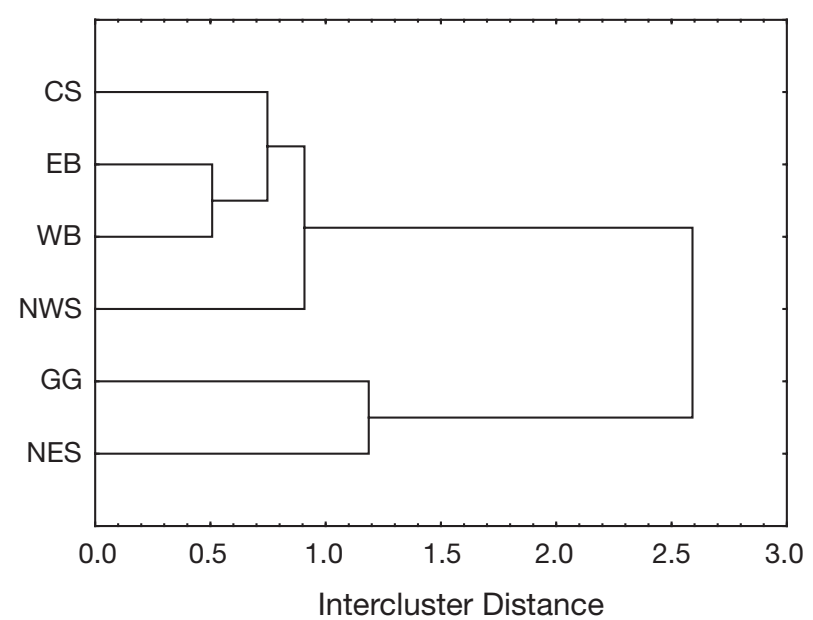

Fig. 5. Similarities among strata derived from continuous and nominal habitat variables. Cluster analysis using Ward's minimum-variance method. Abbreviations as in Fig. 4

habitat. Instead, results reveal a significant association between juvenile presence and certain habitat features, namely sites at least $80 \mathrm{~cm}$ deep during high and flood tides, with undercuts and/or well-developed canopy and overhangs, which provide both shade and structural complexity underwater. Depth preference might be a reflection of sites that do not dry out during low tides. Although only 52 juveniles is a small number to make any strong conclusions about habitat use, small sample size is a limitation often encountered with endangered and protected species whose numbers have been reduced to a fraction of their original population size. Habitat preferences reported here are similar to those found in previous juvenile Epinephelus itajara habitat studies conducted in the fringing red mangroves of Ten Thousand Islands, where juveniles were found also in sites with eroded shorelines, extensive undercuts, and high bathymetric complexity (A. M. Eklund et al. unpubl. data). However, this is the first time that juvenile habitat use has been confirmed by visual underwater census, and that the use of limestone solution holes and the underside of dead trees has been reported in the literature.

The association of small groupers with structurally complex habitats may reduce foraging time and exposure to predators (Eggleston 1995), although it is difficult to distinguish the relative importance of these 2 factors separately. Fish are attracted to shade-producing structures for visual advantage because potential prey and predators are easier to detect from shaded versus sunlit positions (Helfman 1981). Shade and structural complexity (defined as prop root density) in mangrove habitats attract fish although the relative importance of each factor varies by species (Cocheret de la Moriniere et al. 2004). Habitat structural complexity alone does not account for higher concentrations of invertebrate-consuming fish. Rather it is the combination of structural complexity, food availability, and shelter from predators provided by the mangrove habitat which is responsible for higher concentration of juvenile fishes (Laedgsgaard \& Johnson 2001). Predation by other fish and sharks is a possible factor influencing the association of juvenile Epinephelus itajara with complex habitat structures. Based on the size range surveyed (12 to $110 \mathrm{~cm} \mathrm{TL}$ ), common predatory fish in the study area such as snappers Lutjanus sp. and great barracuda Sphyraena barracuda may predate on the smaller juveniles ( $<20 \mathrm{~cm}$ TL). Sharks have been reported to attack juvenile $E$. itajara caught on set lines deployed along mangrove shorelines in the Ten Thousand Islands (Sadovy \& Eklund 1999). Bull Sharks Carcharinus leucas, blacktip sharks C. limbatus and lemon sharks Negaprion brevirostris were all observed during our work in the study area.

The need for structurally complex habitat reported above might explain the differences in juvenile abundance and distribution among strata. In the PCA (Fig. 4) transects from the GG strata segregate mostly towards the higher complexity region of the graph, although some transects from the other strata (not containing juveniles) are also found in this region. Cluster analysis (Fig. 5), shows GG and NES strata as a unique cluster indicating structural similarity. Most of these strata were exclusively overwash mangrove islands with 
extensive canopy, overhangs, and undercuts (only found here) which explains the higher abundance of groupers found ( 7 in NES, 39 in GG). The large keys (EB and WB) and NWS were mostly depositional very shallow $(<80 \mathrm{~cm})$ dwarf mangrove forests, with extensive prop root systems. Groupers were only found in the few sections of eroded and deeper shoreline (3 in EB, 3 in WB, 0 in NWS). The CS stratum was intermediate between the mostly depositional EB and WB and the mostly erosional and structurally complex GG and NES.

Mangrove habitats, although critical nursery areas for many fish species, continue to be threatened from modification, degradation and destruction in the southeastern US and throughout tropical and subtropical regions worldwide (Gilmore \& Snedaker 1993, Strong \& Bancroft 1994, Serafy et al. 2003, Manson et al. 2005). Well-established mangrove forests with high underwater spatial complexity contain the highest number of fish and invertebrate species (Manson et al. 2005). Results reported here show that juvenile Epinephelus itajara prefer well-developed fringing red mangrove shorelines with high spatial complexity. From a goliath grouper conservation perspective, such sites are the most valuable habitat in need of protection. Monitoring the abundance and distribution of juveniles along the mangrove habitats may help evaluate E. itajara population trends in the Florida Keys.

Acknowledgements. I thank P. Barroso for his assistance during strenuous fieldwork, D. DeMaria for reporting the first juvenile sightings in the Florida Keys, M. Laudicina for his advice during fieldwork, A. M. Eklund for guidance during the development of this research, J. A. Bohnsack and J. E. Serafy and 3 anonymous reviewers for comments on earlier drafts. Funding was provided by a National Research Council Postdoctoral Fellowship, and NOAA Fisheries' Coral Reef Conservation Program. Views expressed herein are those of the author and do not necessarily reflect the views of any supporting agency.

\section{LITERATURE CITED}

Bohnsack JA, McClellan DB, Harper DE, Davenport GS and 15 others (1999) Baseline data for evaluating reef fish populations in the Florida Keys, 1979-1998. NOAA Tech Mem NMFS-SEFSC-427

Bullock LH, Murphy MD, Godcharles MF, Mitchell ME (1992) Age, growth, and reproduction of jewfish, Epinephelus itajara, in the eastern Gulf of Mexico. Fish Bull 90:243-249

Cocheret de la Moriniere E, Nagelkerken I, van der Meij H, van der Velde G (2004) What attracts juvenile coral reef fish to mangroves: habitat complexity or shade? Mar Biol 144:139-145

Eggleston DB (1995) Recruitment of Nassau grouper Epinephelus striatus: post-settlement abundance, microhabitat features and ontogenetic habitat shifts. Mar Ecol Prog Ser 124:9-22

Editorial responsibility: Cornelius Hammer, Rostock, Germany
Eklund AM, Schull J (2001) A stepwise approach to investigate the movement patterns and habitat utilization of goliath grouper, Epinephelus itajara, using conventional tagging, acoustic telemetry and satellite tracking. In: Nielsen JL (ed) Electronic tagging and tracking in marine fisheries. Kluwer Academic Publishers, Amsterdam, p 189-216

Gilmore RG, Snedaker SC (1993) Mangrove forests. In: Echternacht AC (ed) Biodiversity of the Southeastern United States: lowland terrestrial communities. John Wiley \& Sons, New York, p 165-198

Heemstra PC, Randall JE (1993) FAO species catalogue: Ggroupers of the world (Family serranidea, subfamily Epinephelinae). An annotated and illustrated catalogue of the grouper, rockcod, hind, coral grouper and lyretail species known to date. FAO Fish Synop 16 (125):1-382

Helfman GS (1981) The advantage to fishes of hovering in shade. Copeia 1981 (2):392-400

Hudson EJ, Mace GM (1996) Marine fish and the IUCN Red List of Threathened Animals. In: Hudson EJ, Mace GM (eds) Report of the IUCN-WWF Workshop at the Zoological Society of London, April 29-May 1, 1996, p 1-26

Huntsman GR, Potts J, Mays RW, Vaughan D (1999) Groupers (Serranidae, Epinephelinae): endangered apex predators of reef communities. In: Musick JA (ed) Life in the slow lane: ecology and conservation of long-lived marine animals. Am Fish Soc Symp 23:217-231

Kaiser HF (1960) The application of electronic computers to factor analysis. Educ Psychol Meas 20:141 - 151

Laedgsgaard P, Johnson C (2001) Why do juvenile fish utilize mangrove habitats? J Exp Mar Biol Ecol 257:229-253

Manson FJ, Loneragan NR, Skilleter GA, Phinn SR (2005) An evaluation of the evidence for linkages between mangroves and fisheries: a synthesis of the literature and identification of research directions. Oceanogr Mar Biol Annu Rev 43:485-515

Milligan GW (1980) An examination of the effect of 6 types of error perturbation on fifteen clustering algorithms. Psychometrika 45:325-342

Odum WE, McIvor CC, Smith TJ (1982) The ecology of the mangroves of South Florida: a community profile. Fish and Wildlife Service, Office of Biological Services, FWS/OBS81-24, Washington, DC

Sadovy Y, Eklund AM (1999) Synopsis of biological information on the Nassau grouper, Epinephelus striatus (Bloch 1792) and the jewfish, E. itajara (Lichtenstein 1822). NOAA Tech Rep NMFS 146

Serafy JE, Lindeman KC, Hopkins TE, Ault JS (1997) Effects of freshwater canal discharge on fish assemblages in a subtropical bay: field and laboratory observations. Mar Ecol Prog Ser 160:161-172

Serafy JE, Faunce CH, Lorenz JJ (2003) Mangrove shoreline fishes of Biscayne Bay, Florida. Bull Mar Sci 72(1):161-180

Smith GB (1976) Ecology and distribution of eastern Gulf of Mexico reef fishes, Fla Mar Res Inst Publ 19:1-78

Sokal RR, Rohlf FJ (1995) Biometry: the principles and practices of statistics in biological research, 3rd edn. W.H. Freeman \& Co, New York

Strong AM, Bancroft GT (1994) Pattern of deforestation and fragmentation of mangrove and deciduous seasonal forests in the upper Florida Keys. Bull Mar Sci 54:795-804

Underwood AJ (1997) Experiments in ecology: their logical design and interpretation using analysis of variance. Cambridge University Press, Cambridge

Submitted: November 10, 2005; Accepted: February 21, 2006 Proofs received from author(s): March 15, 2006 